\title{
ドパミン神経系賦活化薬の慢性投与は自閉症モデルマウスの行動異常を改善する
}

\author{
原雄大
}

\section{Chronic Activation of the Dopaminergic Neuronal Pathway Improves Behavioral Abnormalities in the Prenatal Valproic Acid Exposure Mouse Model of Autism Spectrum Disorder}

\author{
Yuta Hara \\ Cell Biology Laboratory, School of Pharmacy, Kindai University; \\ 3-4-1 Kowakae, Higashiosaka, Osaka 577-8502, Japan.
}

(Received May 20, 2019)

\begin{abstract}
Over the last decade there has been an increase in the prevalence of autism spectrum disorder (ASD); however, its pathogenic mechanisms remain unclear. To date, no effective drug has been developed to treat the core symptoms of ASD, especially social interaction deficits. Previous studies have mainly focused on the glutamatergic, GABAergic, and serotonergic signaling pathways; however, a growing number of studies have reported abnormalities in the dopaminergic pathway, such as mutations and functional alterations of dopamine-related molecules, in ASD patients. Furthermore, atypical antipsychotic drugs risperidone and aripiprazole are prescribed for the treatment of non-core symptoms, such as irritability, in patients with ASD. These observations suggest that the dopaminergic pathway is involved in the pathogenesis of ASD. Previously, we have established a mouse model of ASD based on clinical research, which shows that exposure to valproic acid, an antiepileptic drug, during pregnancy causes an increase in the risk of developing ASD in children. This review summarizes our recent studies, which have assessed alterations in the prefrontal dopaminergic pathway. In addition, we discuss the effects of treatment with attention deficit/hyperactivity disorder drugs and atypical antipsychotic drugs, which activate the prefrontal dopaminergic pathway, on ASD-like behavioral abnormalities in the valproic acid exposure mouse model of ASD.
\end{abstract}

Key words_ autism; valproic acid; dopamine; prefrontal cortex; animal model

\section{1. はじめに}

自閉スペクトラム症（autism spectrum disorder; ASD）は，社会性の障害，コミュニケーションの 障害，常同行動や興味・活動の限局化の 3 つを主症 状とする神経発達障害である. ${ }^{1)}$ その患者数は, 年 々増加しており，現在有病率は 59 人に 1 人の割合 となっている. ${ }^{2)}$ 発症原因はいまだ不明であるが, 遺伝的要因と環境要因との相互作用により発症する と考えられており，近年，欧米を始め世界で ASD の有病率が劇的に上昇していることや，双生児を対 象とした疫学調査での知見より, 環境要因の占める 割合は $55 \%$ にも及ぶと算出されている. ${ }^{3)}$ また，妊 娠中のウイルス感染やビタミン不足により ASD の

近畿大学薬学部細胞生物学研究室 (干577-8502 大阪府 東大阪市小若江 3-4-1)

e-mail: hara@phar.kindai.ac.jp

本総説は, 2018 年度日本薬学会関西支部奨励賞（生物

系薬学）の受賞を記念して記述したものである.
発症リスクが増大することが示され，胎生期・周産 期の環境要因についても，広義の意味で，ASD 発 症に係わる環境因子として考えられるようになっ た。したがって，最近の国内外の ASD に関する基 礎研究では，胎生期〜幼児期の環境要因の役割解明 を目的とする研究が目立つようになってきた。しか しながら，ASD の病態発現に係わる分子基盤はい まだ明らかではなく，また，主症状に対して有効性 を示す薬物はいまだ存在しない.

バルプロ酸（valproic acid; VPA）は，てんかん や双極性障害の治療など広く臨床応用されている薬 物であり，妊娠可能な女性のてんかん患者にとって しばしば唯一の治療選択肢とされている。一方, 抗 てんかん薬を妊娠中に服用した女性から生まれた子 供では，奇形や精神遅滞などの障害を持つリスクが 高いこと，なかでもVPA の服用による発症リスク が最も高いことが報告された. 4 ,5) このような臨床知 見を背景に, 胎生期にVPA を投与したげっ歯類, 
特にラットが自閉症のモデル動物として用いられて きた. ${ }^{6,7)}$ 筆者らは，既存の遺伝子改変自閉症モデル マウスとの比較が容易であること，遺伝子-環境相 互作用の解析が可能であるなどの理由から，胎生期 の VPA 投与によるマウスでの自閉症モデルの作製 を試みた。そして，胎生 12.5 日目にVPA $(500 \mathrm{mg}$ / $\mathrm{kg}$ ）を投与した ICR 系マウス由来のオスの出生仔 が，種々の ASD 様の行動異常を示すこと,8,9) 大脳 皮質での神経細胞数の減少8) や海馬での樹状突起又 パイン密度の低下9) といった脳組織学的変化が起き ていることを明らかにした。

自閉症の発症には, 脳内の神経伝達物質の異常が 関与していると考えられている。これまでは，興奮 性神経と抑制性神経のバランスの乱れによる発症仮 説の広まりから，グルタミン酸神経系や GABA 神 経系に焦点を当てた研究が数多く行われてきた. ${ }^{10)}$ また，ASD 患者におけるドパミン受容体などのド パミン神経系関連遺伝子の变異やタンパク質の機能 変化が近年報告されているが, ${ }^{11)}$ ドパミン神経系の 変化と自閉症の病態発現との関連性の詳細は不明で ある。また，注意欠陥多動性障害（attention deficit hyperactivity disorder; ADHD）治療薬や抗精神病 薬などのドパミン神経系を標的とした薬物が，多動 や易刺激性などの ASD の付随症状の改善に使用さ れているが, ${ }^{12)}$ その作用機序についても不明である.

本稿では，胎生期 VPA 曝露マウスにおいてこれ まで筆者らが見い出した知見を中心として，ASD におけるドパミン神経系の変化及びその治療標的と しての可能性について考察する。

\section{2. 自閉症モデルマウスにおけるドパミン神経系 機能の低下}

筆者らは，モノアミン含量，代謝回転及び基礎遊 離量の観点より，ASD モデルマウスの定常状態に おけるドパミン神経系の変化を検討したが，ドパミ ン神経系の主要な投射先である前頭前皮質及び線条 体において，いずれも対照群と差異はなく，また， ノルアドレナリン及びセロトニンなど他のモノアミ ンについても群間で差異は認められなかった.

ASD 患者では，外部からの刺激の入力により多 動などの異常な行動を示すこと, 社会性行動や他者 とのコミュニケーションに障害があることなどが特 徵として知られており，外的な刺激に対する神経細 胞の応答性が障害されていることが示唆される。そ

こで筆者らは，中枢興奮薬であるメタンフェタミン を用いた薬理学的手法により，モデル動物の神経細 胞の応答性変化を追究した. メタンフェタミンは, げっ歯動物において，自発運動量，脳内のモノアミ ン遊離量，並びに神経活動を増加させることが知ら れている. ${ }^{13,14)}$ オスの ASD モデルマウスでは, メ タンフェタミンによる運動量, 並びに前頭前皮質で のドパミン遊離量及び神経活性化マーカー c-Fos 夕 ンパク質の増加作用が有意に減弱していた（Fig. 1).さらに，モデルマウスの前頭前皮質において， ドパミン $\mathrm{D}_{1}$ 及び $\mathrm{D}_{2}$ 受容体の $\mathrm{mRNA}$ 発現量が減少 していた。一方，メタンフェタミンによる前頭前皮 質での他のモノアミン遊離量の増加作用に影響はな く,さらに線条体ではいずれの変化も認められな かつた。 メタンフェタミンによる運動量の増加作用 には，前頭前皮質のドパミン $\mathrm{D}_{1}$ 及び $\mathrm{D}_{2}$ 受容体が 関与していること, ${ }^{14,15)}$ また, c-Fos 陽性細胞数の 増加作用にはドパミン $\mathrm{D}_{1}$ 及び $\mathrm{D}_{2}$ 受容体が関与し ていること16,17) が報告されている。これらの報 告，及び線条体ではドパミン受容体の発現量に変化 がなかったことより，ASD モデルマウスで認めら れたメタンフェタミンに対する薬理学的感受性の低 下は，前頭前皮質のドパミン神経系の機能低下に起 因する可能性が考えられた。

ASD は，男児に多いという性差が知られてい る. ${ }^{18)}$ 臨床知見と一致して，筆者らは，本モデルマ ウスでの社会性行動障害が，オスマウスのみ発現す ることを認めている. ${ }^{8,19)}$ また，前頭前皮質のドパ ミン神経系の機能低下に関しても，メスのモデルマ ウスでは発現しないことを認めた.

これらの知見より，胎生期の抗てんかん薬投与誘 発の ASD モデルマウスにおいて，オスの前頭前皮 質特異的にドパミン神経系の機能低下が生じている ことが明らかとなった。

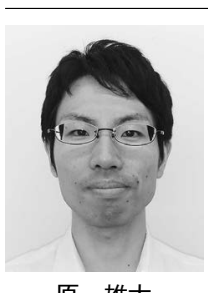

原 雄大
2011 年 3 月に大阪大学薬学部を卒業 後, 同大大学院薬学研究科（薬物治療 学分野：主宰 松田敏夫教授, 神経薬理 学分野: 主宰 橋本 均教授)に進学し 2017 年 3 月に博士 (薬科学) を取得す る. 2017 年 4 月より近畿大学薬学部の 助教に着任し, 現在に至る. 
Prefrontal cortex

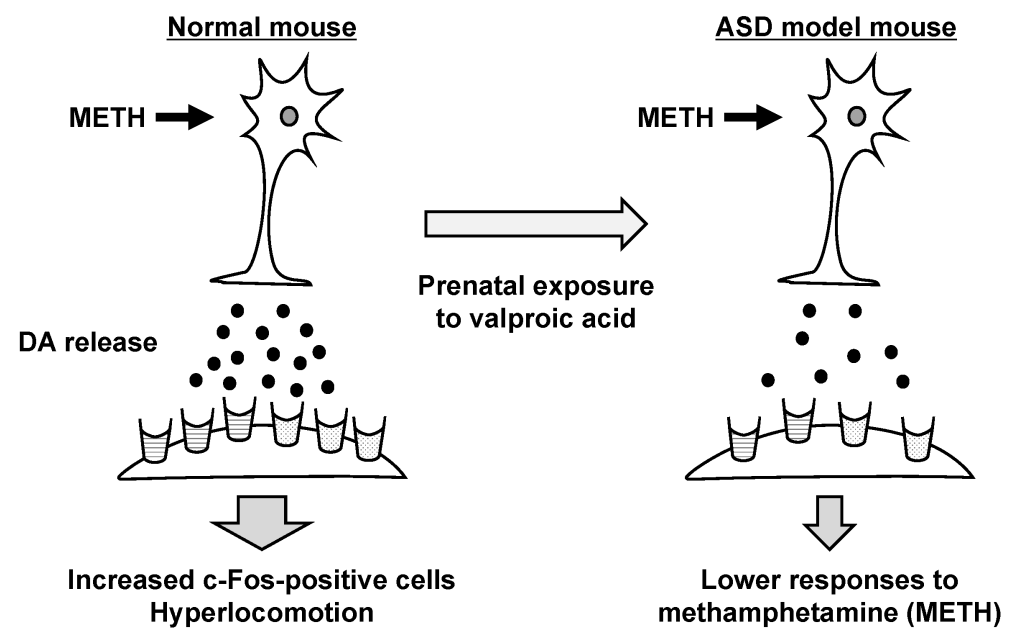

- DA $Y$ DA-D $_{1}$ receptor $Y_{\mathrm{DA}-\mathrm{D}_{2} \text { receptor }}$

Fig. 1. Reduced Prefrontal Dopaminergic Function in a Mouse Model of Autism Spectrum Disorder

Prenatal exposure to valproic acid decreased the pharmacological response to methamphetamine, such as dopamine release and increased c-Fos-positive cells in the prefrontal cortex, and hyperlocomotion. METH: methamphetamine, DA: dopamine, ASD: autism spectrum disorder.

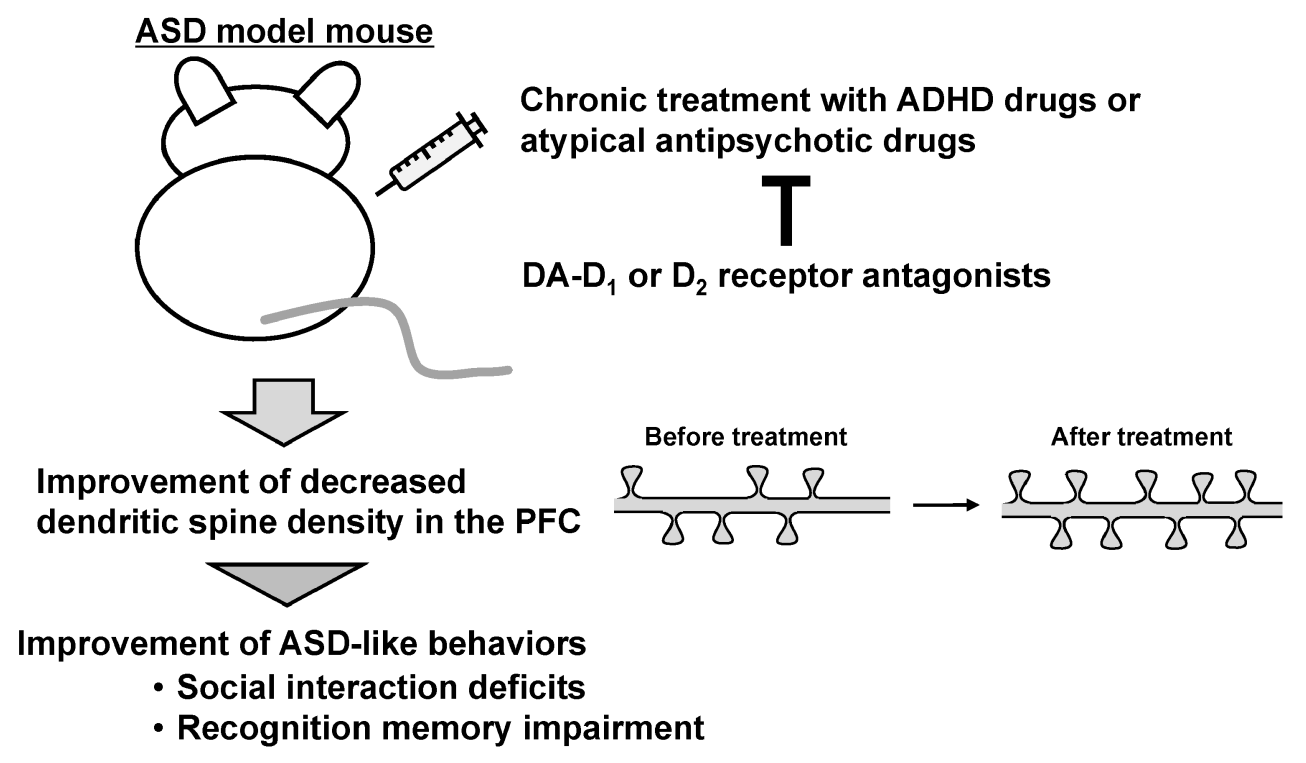

Fig. 2. Chronic Treatment with ADHD and Atypical Antipsychotic Drugs Ameliorate ASD-like Behavioral Abnormalities and the Loss of Dendritic Spine Morphology in Mice Prenatally Exposed to Valproic Acid

ADHD: attention deficit hyperactivity disorder, PFC: prefrontal cortex, ASD: autism spectrum disorder.

\section{ASD 様の行動異常に対するドパミン神経系} 賦活化薬の効果

つぎに，メタンフェタミンに対する薬理学的応答 性を指標に見い出した前頭前皮質のドパミン神経系 の機能低下について, ASD の治療標的としての可 能性について追究した. ADHD の治療薬であるメ チルフェニデート及びアトモキセチンは, 低用量で 慢性投与すると，マウスの前頭前皮質選択的にドパ
ミン神経系を活性化することが知られている。 ${ }^{20)}$ 筆 者らは, in vivo 脳微小透析法により, メチルフェ ニデート及びアトモキセチンが，ASD モデルマウ スの前頭前皮質におけるドパミン遊離量を増加させ ることを見い出し，また両薬物が， 2 週間の慢性投 与により社会性行動の障害及び付随症状の 1 つであ る認知記憶の障害を改善することを明らかとした (Fig. 2). 
樹状突起スパインは, 神経細胞上に存在し, 興奮 性の神経伝達を担う微小な構造である。近年, ASD の病態発現への樹状突起スパインの関与が注 目されており, ${ }^{21)}$ 最近 Kang らは，樹状突起スパイ ンの変化と行動学的変化との関連について，樹状突 起スパインの成熟に係わる IRSp53 の欠損マウスが 社会性行動及び認知記憶の障害を示すことを報告し ている. ${ }^{22)}$ また筆者らは，ASD モデルマウスの前 頭前皮質において樹状突起スパイン密度が減少して いること，ADHD 治療薬の慢性投与により，その 低下が改善することを見い出した（Fig. 2)。また，

ADHD 治療薬によるASD 様行動及びスパイン形 態学的異常の改善作用は, ドパミン $\mathrm{D}_{1}$ 受容体拮抗 薬 $\mathrm{SCH} 39166$ 若しくは $\mathrm{D}_{2}$ 受容体拮抗薬ラクロプリ ドとの併用投与により拮抗され，アドレナリン $\alpha_{2}$ 受容体拮抗薬イダゾキサンとの併用投与により影響 を受けなかった。

非定型抗精神病薬であるリスペリドン及びアリピ プラゾールは，ADHD 治療薬とは異なる作用発現 機序を持つが，メチルフェニデート及びアトモキセ チンと同様にマウス前頭前皮質のドパミン神経系を 活性化させる. ${ }^{23,24)}$ 一方，定型抗精神病薬である八 ロペリドールにはそのような作用は認められな い. ${ }^{25)}$ 前頭前皮質のドパミン神経系の活性化作用と 相関して，リスペリドン及びアリピプラゾールは, 慢性投与により ASD モデルマウスの行動異常及び 樹状突起スパイン密度の低下を改善させ（Fig. 2), 一方，ハロペリドールでは効果が認められなかつ た。なお，リスペリドン及びアリピプラゾールは, 単回投与では ASD 改善作用を示さなかったことよ り，作用発現には持続的あるいは反復的なドパミン 神経系の活性化が必要であることが示唆される。

4. おわりに

筆者らは，オスの ASD モデルマウスにおいて， 前頭前皮質のドパミン神経系特異的に機能が低下し ていること, ${ }^{26)}$ さらに，前頭前皮質のドパミン $\mathrm{D}_{1}$ 及び $\mathrm{D}_{2}$ 受容体の慢性的な活性化がモデルマウスの ASD 様の行動異常及び樹状突起スパイン密度の低 下を改善すること27,28)を示した。

神経精神疾患のモデル動物は, 表面妥当性, 構成 妥当性及び予測妥当性の 3 つを満たすことが望まし いとされている. ${ }^{29)}$ これまでに, Cntnap2 欠損マウ ス $^{30)}$ 及び NL3 $3^{\mathrm{R} 451 \mathrm{C}}$ マウス ${ }^{31)}$ といつた単一遺伝子変
異による ASD モデル動物において，すべての妥当 性を満たすことが示されているが，多因子要因を持 ち，実際の病因をより反映するとして用いられてい るモデル動物において，3つの妥当性を満たすもの は知られていない，筆者らは，VPA を曝露した胎 仔由来の全脳及び大脳皮質神経細胞において, $\mathrm{MeCP} 2$, Shank2, 及び Neuroligin-1 などの複数の ASD 関連遺伝子の発現が変動することを見い出し ている. ${ }^{32,33)}$ また，最近の臨床試験において，ASD 患者の主症状に対して改善効果が見い出された神経 ペプチドであるオキシトシンが, ${ }^{34)}$ 本モデルマウス の社会性行動障害を改善することを明らかとしてい る. ${ }^{35)}$ すなわち，本モデルマウスにおいて筆者らが 見い出した一連の知見は，本マウスが ASD の表面 妥当性（性差を含む ASD 様の行動異常の発現）, 構成妥当性（ASD 関連遺伝子群の発現変動）及び 予測妥当性（オキシトシンによる ASD 様行動の改 善効果）を満たすことを示しており，本モデルマウ スが妥当性の高い非常に有益な ASD モデルである ことが考えられる。したがって，本モデルマウスよ り得られた今回の知見は，ASD におけるドパミン 神経系の機能低下の重要性，及びドパミン神経系を 標的とする薬物治療の可能性を強く提唱するもので あり，いまだ有効性を示す薬物が存在しない ASD の治療において，新たな情報とアイディアを提供 し，大きな発展をもたらすものと期待される。

\section{謝辞本研究を行うにあたり, 終始懇切な御指} 導, 御鞭撻を賜りました大阪大学大学院薬学研究科 薬物治療学分野 松田敏夫名誉教授, 神経薬理学分 野 橋本 均教授, 歯学研究科薬理学教室 田熊一敞 教授, 並びに薬学研究科薬剤学分野 吾鄉由希夫准 教授に心より厚く御礼申し上げます。また，本研究 を遂行するにあたり協力頂きました大阪大学大学院 薬学研究科薬物治療学分野のメンバー諸氏に感謝い たします。

\section{利益相反＼cjkstart開示すべき利益相反はない.}

\section{REFERENCES}

1) Geschwind D. H., Levitt P., Curr. Opin. Neurobiol., 17, 103-111 (2007).

2) Baio J., Wiggins L., Christensen D. L., Maen- 
ner M. J., Daniels J., Warren Z., KurziusSpencer M., Zahorodny W., Robinson Rosenberg C., White T., Durkin M. S., Imm P., Nikolaou L., Yeargin-Allsopp M., Lee L. C., Harrington R., Lopez M., Fitzgerald R. T., Hewitt A., Pettygrove S., Constantino J. N., Vehorn A., Shenouda J., Hall-Lande J., Van Naarden Braun K., Dowling N. F., $M M W R$ Surveill. Summ., 67, 1-23 (2018).

3) Hallmayer J., Cleveland S., Torres A., Phillips J., Cohen B., Torigoe T., Miller J., Fedele A., Collins J., Smith K., Lotspeich L., Croen L. A., Ozonoff S., Lajonchere C., Grether J. K., Risch N., Arch. Gen. Psychiatr., 68, 10951102 (2011).

4) Williams P. G., Hersh J. H., Dev. Med. Child Neurol., 39, 632-634 (1997).

5) Christensen J., Grønborg T. K., Sørensen M. J., Schendel D., Parner E. T., Pedersen L. H., Vestergaard M., JAMA, 309, 1696-1703 (2013).

6) Schneider T., Przewłocki R., Neuropsychopharmacology, 30, 80-89 (2005) .

7) Kim K. C., Kim P., Go H. S., Choi C. S., Yang S. I., Cheong J. H., Shin C. Y., Ko K. H., Toxicol. Lett., 201, 137-142 (2011).

8) Kataoka S., Takuma K., Hara Y., Maeda Y., Ago Y., Matsuda T., Int. J. Neuropsychopharmacol., 16, 91-103 (2013) .

9) Takuma K., Hara Y., Kataoka S., Kawanai T., Maeda Y., Watanabe R., Takano E., Hayata-Takano A., Hashimoto H., Ago Y., Matsuda T., Pharmacol. Biochem. Behav., 126, 43-49 (2014).

10) Nelson S. B., Valakh V., Neuron, 87, 684-698 (2015).

11) Nguyen M., Roth A., Kyzar E. J., Poudel M. K., Wong K., Stewart A. M., Kalueff A. V., Neurochem. Int., 66, 15-26 (2014) .

12) Goel R., Hong J. S., Findling R. L., Ji N. Y., Int. Rev. Psychiatry, 30, 78-95 (2018).

13) Ago Y., Araki R., Yano K., Hiramatsu N., Kawasaki T., Chaki S., Nakazato A., Onoe H., Hashimoto H., Baba A., Takuma K., Matsuda T., Psychopharmacology (Berl.), 217, 443-452 (2011).

14) Hall D. A., Powers J. P., Gulley J. M., Brain Res., 1300, 51-57 (2009).

15) Wang J. Q., McGinty J. F., J. Neurochem.,
65, 2706-2715 (1995) .

16) Zahniser N. R., Simosky J. K., Mayfield R. D., Negri C. A., Hanania T., Larson G. A., Kelly M. A., Grandy D. K., Rubinstein M., Low M. J., Fredholm B. B., J. Neurosci., 20, 5949-5957 (2000).

17) Nagai T., Takuma K., Kamei H., Ito Y., Nakamichi N., Ibi D., Nakanishi Y., Murai M., Mizoguchi H., Nabeshima T., Yamada K., Learn. Mem., 14, 117-125 (2007) .

18) Miles J. H., Genet. Med., 13, 278-294 (2011).

19) Hara Y., Maeda Y., Kataoka S., Ago Y., Takuma K., Matsuda T., J. Pharmacol. Sci., 118, 543-546 (2012).

20) Koda K., Ago Y., Cong Y., Kita Y., Takuma K., Matsuda T., J. Neurochem., 114, 259-270 (2010) .

21) Penzes P., Cahill M. E., Jones K. A., VanLeeuwen J. E., Woolfrey K. M., Nat. Neurosci., 14, 285-293 (2011).

22) Kang J., Park H., Kim E., Neuropharmacology, 100, 27-39 (2016).

23) Hertel P., Nomikos G. G., Iurlo M., Svensson T. H., Psychopharmacology (Berl.), 124, 7486 (1996).

24) Bortolozzi A., Díaz-Mataix L., Toth M., Celada P., Artigas F., Psychopharmacology (Berl.), 191, 745-758 (2007).

25) Kuroki T., Meltzer H. Y., Ichikawa J., J. Pharmacol. Exp. Ther., 288, 774-781 (1999).

26) Hara Y., Takuma K., Takano E., Katashiba K., Taruta A., Higashino K., Hashimoto H., Ago Y., Matsuda T., Behav. Brain Res., 289, 39-47 (2015).

27) Hara Y., Ago Y., Taruta A., Katashiba K., Hasebe S., Takano E., Onaka Y., Hashimoto H., Matsuda T., Takuma K., Autism Res., 9, 926-939 (2016).

28) Hara Y., Ago Y., Taruta A., Hasebe S., Kawase H., Tanabe W., Tsukada S., Nakazawa T., Hashimoto H., Matsuda T., Takuma K., Psychopharmacology (Berl.), 234, 3217-3228 (2017).

29) Nestler E. J., Hyman S. E., Nat. Neurosci., 13, 1161-1169 (2010).

30) Peñagarikano O., Lázaro M. T., Lu X. H., Gordon A., Dong H., Lam H. A., Peles E., Maidment N. T., Murphy N. P., Yang X. W., Golshani P., Geschwind D. H., Sci. Transl. 
Med., 7, 271ra8 (2015).

31) Burrows E. L., Laskaris L., Koyama L., Churilov L., Bornstein J. C., Hill-Yardin E. L., Hannan A. J., Mol. Autism, 6, 62 (2015).

32) Kawanai T., Ago Y., Watanabe R., Inoue A., Taruta A., Onaka Y., Hasebe S., Hashimoto H., Matsuda T., Takuma K., Neurochem. Res., 41, 2574-2584 (2016).

33) Hara Y., Ago Y., Takano E., Hasebe S., Nakazawa T., Hashimoto H., Matsuda T.,
Takuma K., Mol. Autism., 8, 33 (2017).

34) Watanabe T., Kuroda M., Kuwabara H., Aoki Y., Iwashiro N., Tatsunobu N., Takao H., Nippashi Y., Kawakubo Y., Kunimatsu A., Kasai K., Yamasue H., Brain, 138, 34003412 (2015).

35) Hara Y., Ago Y., Higuchi M., Hasebe S., Nakazawa T., Hashimoto H., Matsuda T., Takuma K., Horm. Behav., 96, 130-136 (2017). 